\begin{tabular}{lcc}
\hline Volume 17 & March 1954 & No. 12 \\
\hline & Original &
\end{tabular}

From the Third Medical Clinic of Kyoto University (Director: Professor M. Maekawa, M. D.)

\title{
Analatical Study of the Lymphon-Allergy IV
}

By

RYOHEI ICHIHARA

(Received for Publication, Oct. 22, 1950)

\section{淋巴腺ホスファテイドを以てせる淋巴球系アレルギー（リンホン・アレルギー (前川)）の分析的研究 第 4 報}

\author{
自然牛血清或は卵蛋白と淋巴腺ホスファテイドとに依るリンホン・アレルギー \\ の分析 其の二
}

\author{
㗨 學士市原 亮平

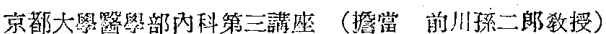

In order to expand the serial studies already published in the 1st, 2nd and 3rd report, the author has undertaken this study which consists in supravital staining and the histological observation: When the "lymphon allergy" takes place, there is lymphocytosis, increase of young lymphocytes, appearance of lymphoblasts with concomitant degeneration, increase of the average mitochondria count, but no change occurs as to erythrocytes, reticulocytes, thrombocytes and

\section{緒}

言

ミトコンドリア(糸粒體)は高木1) に依れば，動物細胞 の全てに存在し，例外は僅かに哺乳類の赤血球と表度角 厤細胞位のものであるという，植物細胞に於てもGuilliermond 〕依れば，總ての細胞に存在し僅かに細菌類 と點藻類では不在を證明したという。（以下ミトコンド リアをミトと略訅する) Girudが依れば，細胞質とミ トは物質の集合狀態が異るもので，ミトと唀明質 (hyaloplasm) は二つの相よりなる一系で，透明質に存在せぬ もので特にミトの中に在るという物質はない. Hurst and Strong ${ }^{4)}$ の如くミトを細胞質から切り離して自律性ある 小體として取扱う傾向は㕍々みとめられる. Kater ${ }^{i)}$ (1931 年) は猫の肝細胞でインシュリン，アドレナリン等の注 射でミトの球形化と肥大を見, Clark and Hair (1932), Hall and Mackay7) (1933)はアドレナリン注射によるミ トの球嫄化と肥大を報告している，Kater 5) は之を細胞 の水分含有量の增加に歸し, 細胞全娟の水分霄加はミト の水分增加從つて球形化と肥大渻くのであると。これ によつて兌れば自己の形態を調節し維持する意味に於て leukocytes (except for lymphocytes). The number of plasma cells present in the peripheral blood becomes very few, while that in bone marrow shows a great increase.

As to the histological findings, the lymphatic tissues of lymphnodes, tonsils, spleen, lungs and liver were found to be affected, but there was almost no appreciable change in other organs and tissues.

は，ミトは自律性を持たないか或は持つても極めて弱い ものであるといわねばならぬ，細胞體內の排列について も，Pollister ${ }^{8)}$ (1932) は細胞質の分子排列 と關聯せしめ て說明しょ5とした。 Freywyssling9) (1938) は原形質は 蛋白質ミセルが持つ多くの侧鎻でゆるやかな結合狀態に あり，その則鎻は化學的親和为により或は親水性，親り ポイド性により直接或は間接に結びつくのである．原形 質がゲル狀態となるときは附着はもつと堅固なものとな るであろ5。こう考光ると原形質のゾル狀態とゲル狀態 との差は附着の强さによる程度の涯であることに歸着す る. Wintrobe ${ }^{10)}$ が淋巴芽球は細胞質がゲル状態にあり， 淋巴球はゾル狀態にあるというが，視りポイド性或は親 ホスファテイド性による結合と關聯してリンホンアレル ギーの本態考察に曙光を見出すことは出來ないであろう か.

ミトは要するに細胞質の缺くべからざる有班成分であ るが，何處にでも自由に存在し得るものではなく，その に存在場所と排列は可なり笨屈に制限せられている。 又 Chambers 等の顯微解剖的研究が示す如く，牛流動熊或 
470

は牛固態であり，即ちゲルの狀態にあるといつてもよい のである。 ミ卜數上昇，或はその分布，形態とホスファ テイド乃至はリポイドとの關係もかかる見地より新しく 形態學的清精密汇擎察する必要があると考光られる。

ミトの化學的成分が蛋白質と脂質から成り立つている といらことは 1910 年代から抱かれている考であるが， 1924 年 Cowdry 11) はミ卜は燐脂質性のもので恐らく少 量の蛋白質を有すると述べている. Giroud") と Bensley and Gersh ${ }^{12)}$ は相反する見解をもち，前者は脂質の存在 を主張し，後者は否定はせ妨確證のないものとしてい る. Bensley and Gersh ${ }^{12}$ ) はミトが細胞の最も易變性の 部分であることを指摘し，Policard and Mangenot (1922) は細胞を加熱すると 48 - $50^{\circ} \mathrm{C}$ でミトは確實に消失する ことを述べている. 然るに，Bensley12) は Hoerr ${ }^{13)}$ との 共同研究でミ卜を機械的に大量に分離し脂質の存在を確 實にした。Bensley11)（1937）はミトの分析の結果，蛋白

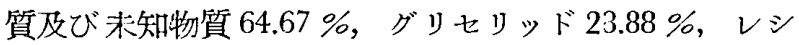
チン・セファリン等 $4.2 \%$ ，コレステロール $2.25 \%$ \%得 た，Goerner ${ }^{15)}$ は香の肝細胞のミトで脂質 27.0 32.4\% の值を得た. 脂質の含有量が高いことは多くの研究者比 よつて主張されるようにミトが廣義のリポイド性のもの であるとの見解を支持寸るものであるが，その主装な脂 質はグリセリッドであつて燐脂質 (phospholipins) でな いことを知ら秝ばならぬ．Giroud ${ }^{3)}$ はミトが蛋白質を含 をことを確認し，前述の如く脂質の存在を認め，ミトは 脂質と蛋白質々の複合體 (complex lipido-proteique) で あると結論している.Joyet-Lavergne1() はミトの恒常成 分としてグルタチオン、ビタミン $\mathrm{A}$ 及び $\mathrm{C}$ があるとい 3. Goerner ${ }^{1 i)}$ はビタミンA を定量して脂質 $100 \mathrm{mg}$ に ついて 249-910 U.S. P. 單位を得た.これは正常家鬼 の場合であるが，造癌物質 dibenzanthracene を腹腔內 注射すると，ミトの脂質は增加して乾燥物質の 40-50 \%にも達するが, ビタミン A は著減し或は全く消失す るという．Marston はミトはヤーヌス綠を始めとしてこ の上万な色素で染まるから蛋白質分解醋素を含むるのと 考光，且つ表面の水泛乏しい相は醉素の合成的活動を助 けるから，ミ卜は細胞內の合成の場所となると考党， Robertson ${ }^{17)}$ は脂質性物質は Gibbs-Thompson 氏法則によ り，ミトの表層汇集り細胞の賿質性成分の合成に好適の 條件を與えると考觉た。Bourne18) はミトをして細胞の呼 吸中樞としての働きをなすと考劣た。近代的學說はミト の分子構筑として椱合コアサベート (complex coacervate）と考元ているょうである. Bensley14), Ries ${ }^{19)}$ すと ういう考を支持する筫驗を行つている。ミトは時に例外 的な色素で生體的或は超生體的炕染色することがある， 例光ば Guilliermond")はピロール靑・ダーリア紫・スチ 几紫 $5 \mathrm{~B}$ を舉げて居り，これなどもミトのコアサベート 性によつて說明するのが制り易いと思う。

以上の如きミトコドリアの研究より著者は白血球特に 淋巴球及び赤血球等を形態學的に詳細に追究し, ミトの
第 17 叁 第 12 號

細胞體內の分布，形狀，湂度に上る變化，時間的推移等 を家鬼に種々なる注射を行いつつ經過を追 うて觀察し た．而して古典的の血液學的擎察と併せ考兄て，浩血臟 器特に淋巴球系の變化を主として超生體染色所見に基い て深く考察せんとした。

\section{實 驗 方 法}

第 3 報に述べたと同じ家鬼群について，ヤーヌ久綠・ 中性赤超生體染色を行つて併行的に觀察した。組合せは 次重㱛て表示する。

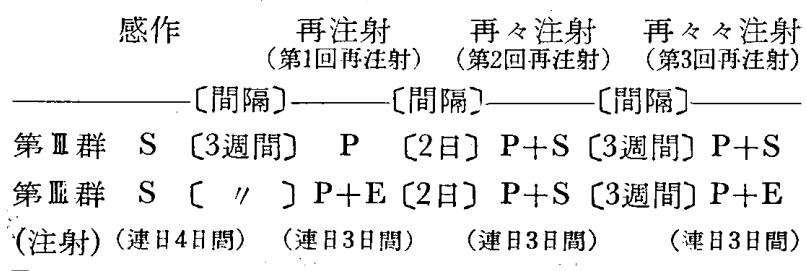

超生體染色觀祭法は第 2 報に於て述べたと同㥞である が，特に緒論に於ても述べ心如く，系粒體（ミトコンド リア)の物理化學的性質を考慮に入れ, 出來得る限り詳

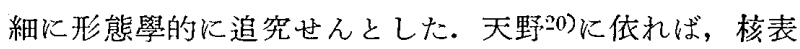
面には凹凸が著しく認められ，核には粗剛なる且つ粘稠 度の大なる核系の梁狀構造が存し, 之が光の屈折强き憵 にこの點のみにて子單球朽至は骨䯈球と相違している, ヤーヌス綠可染の系粒体は, 細胞體內に散在するものが

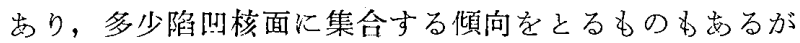
その粒は單球の夫机に比して粗く，且つ㾿及桿狀呈す るものを混ず，中性赤可染空胞は多少集合傾向をとつて 來る場合があるが，その數の多き場合々雖も，單球に見 る如き花冠狀排列を呈することはない.Wintrobe ${ }^{10)}$ は 幼若淋巴球に於てはミトコンドリアが數多く存在し特に 核の一側に在り，淋巴蕂球では無數のミトが核に近く存 在するという。

\section{1. 超址體染色標本觀察}

\section{實 驗 成 績}

第正群: No. 457 牛血清の逨日 4 日間の感作汇よつて は僅かに本均系粒體數が上䒜するのみで, 幼若型の出現 は極めて僅かである，再注射に㴤巴腺「木」の久を連日 3 日間注射するも，僅微の幼若型增加の外著變はみとめ られない，平均系粒體數の上昇も殆んど無いといつてよ い. 然るにその再注射終了後 2 日の間隔を沶いて再及注 射(第 2 回侢注射)に淋巴腺「木」加牛血淸を連日 3 日間 注射すると, 系粒體數 0 -10 估の老型が注射前の約 3 分 の 1 亿減少し，11-20 個のものが約 2 倍に增加し，21一

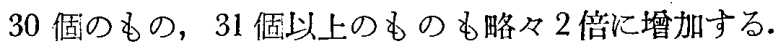
然し乍ら平均系粒體數の增加は輕度にして注射前 10.3 のものが注射後第 2 日に 13.7 子增加したのが最高であ る. この附近の檢査は連日行つているが，平均系粒體數 はかかる注射後に於て日時的繥動をなすや測り難く或 はそれ以上の值を示すべき時刻るあるか子知れないが， 檢索に㭙間を姴する關係上それ以上時間的變化を追う事 が許されなかつた：この點超生體染色所見では，牛血淸 
感作・淋巴腺「ホ」加牛血淸再注射の時の變化よりは輕 度にして，幾分直前に大れた淋巴腺「木」により抑制さ れているのではないかと想像せらる. 更にその第 2 回再 注射後 3 週間にして，第 3 回再注射に淋巴腺「木」加牛 血清を婵日 3 日間注射すると，系粒體數 0 -10 感の子の は非常に減少し，11-20 個のbの6注射前の約牛數に 減少し，それに反して $21-30$ 個のものは注射前の值の 10 倍以上に增加し，31 個以上のものも娾倒的に增加し， 淋巴芽球及び其の變性像も明かに認めることが出來た。 平均系粒體數も注射前 12.4 の もの最高 24.6 迄增加し た. (Table 12), (Fig. 7)

No. 460一No. 457 と同樣な注射を施行して全く同樣 な觀察をなしたが，Tab. 12 及び Fig. 7 に見る如くそ
の變化は No. 457 に於て述べたと殆んど變らぬるので あると言光る。即ち，淋巴腺「ホ」のみの第 1 回再注射 では殆えど變化なくそれれ引續いて行つた淋巴腺「ホ」 加牛血清の再注射によつては，糸粒體數 0 -10 個のもの が牛減，11-20 個のものが約 3 倍に增加，21-30 個の ものが 4 倍出現し，31 個以上の子のは殆んど變化なく， 平均系粒體數も注射前 9.8 の あが 12.2 に增加してい る. 第 3 回再注射として行つた淋巴腺「木」加牛血清注 射後に於ては No. 457 に於けると同樣に，幼若型の著 增、淋巴芽球及び其の變性像を認め, 平均糸䊀體數も注 射前 11.2 のもが注射後最高 25.1 迄賭加した。

No. 457 と No. 460 とを併せ考学ると，6つと詳細に 時間的に經過夲追つて憼察してみなければ明言はしがた

Table 12 (3rd. Group)

\begin{tabular}{|c|c|c|c|c|c|c|c|c|c|}
\hline \multirow[b]{2}{*}{ No. } & & \multicolumn{3}{|c|}{ Size } & \multicolumn{4}{|c|}{ Mitochondria Counts } & \multirow{2}{*}{$\begin{array}{c}\text { Average } \\
\text { Mt } \\
\text { Counts }\end{array}$} \\
\hline & & Small & $\begin{array}{c}\text { Inter- } \\
\text { mediate }\end{array}$ & Large: & $0-10$ & $11-20$ & $21-30$ & 31 more & \\
\hline \multirow{12}{*}{457} & $\begin{array}{c}\text { Before } \\
\text { Sensitization }\end{array}$ & 80 & 16 & 4 & 82 & 17 & 1 & 0 & 6.4 \\
\hline & $\begin{array}{c}\text { After } \\
\text { Sensitization }\end{array}$ & 70 & 23 & 7 & 75 & 22 & 2 & 1 & 8.9 \\
\hline & $\begin{array}{c}\text { Before } \\
\text { 1st. Reinject. }\end{array}$ & 87 & 10 & 3 & 68 & 29 & 2 & 1 & 10.1 \\
\hline & $\begin{array}{l}1 \text { Day } \\
\text { After 1st. Reinj. }\end{array}$ & 86 & 13 & 1 & 49 & 45 & 5 & 1 & 11.6 \\
\hline & $\begin{array}{l}2 \text { Days } \\
\text { After 1st. Reinj. }\end{array}$ & 92 & 8 & 0 & 61 & 34 & 5 & 0 & 10.3 \\
\hline & $\begin{array}{c}1 \text { Day } \\
\text { After } 2 \text { nd. Reinj. }\end{array}$ & 87 & 13 & 0 & 40 & 55 & 5 & 0 & 12.0 \\
\hline & $\begin{array}{c}2 \text { Days } \\
\text { After 2nd. R. }\end{array}$ & 73 & 26 & 1 & 23 & 67 & 8 & 2 & 13.7 \\
\hline & $\begin{array}{c}3 \text { Days } \\
\text { After 2nd. } R \text {. }\end{array}$ & 75 & 24 & 1 & 43 & 55 & 2 & 0 & 11.4 \\
\hline & $\begin{array}{c}\text { Before } \\
\text { 3rd. Reinject. }\end{array}$ & 92 & 6 & 2 & 35 & 61 & 3 & 1 & 12.4 \\
\hline & $\begin{array}{c}1 \text { Day } \\
\text { After } 3 \text { 3rd. } \mathrm{R} . \\
\end{array}$ & 68 & 23 & 9 & 12 & 29 & 26 & 11 & 20.1 \\
\hline & $\begin{array}{c}2 \text { Days } \\
\text { After 3rd. } \mathrm{R} \text {. }\end{array}$ & 52 & 29 & 19 & 1 & 35 & 47 & 17 & 24.6 \\
\hline & $\begin{array}{c}3 \text { Days } \\
\text { After 3rd. R. }\end{array}$ & 87 & 7 & 6 & 2 & 53 & 33 & 12 & 21.3 \\
\hline \multirow{11}{*}{460} & $\begin{array}{c}\text { Before } \\
\text { Sensitization } \\
\end{array}$ & 86 & 12 & 2 & 66 & 34 & 0 & 0 & 9.5 \\
\hline & $\begin{array}{c}\text { After } \\
\text { Sensitization }\end{array}$ & 87 & 8 & 5 & 75 & 22 & 3 & 0 & 9.0 \\
\hline & $\begin{array}{c}\text { Before } \\
\text { 1st. Reinject. } \\
\end{array}$ & 96 & 4 & 0 & 47 & 50 & 3 & 0 & 11.3 \\
\hline & $\begin{array}{l}1 \text { Day } \\
\text { After 1st. Reinj. }\end{array}$ & 93 & 6 & 1 & 65 & 32 & 1 & 2 & 10.4 \\
\hline & $\begin{array}{l}2 \text { Days } \\
\text { After lst. Reinj. }\end{array}$ & 95 & 4 & 1 & 45 & 23 & 1 & 1 & 9.8 \\
\hline & $\begin{array}{l}1 \text { Day } \\
\text { After 2nd. Reinj. }\end{array}$ & 84 & 16 & 0 & 44 & 53 & 2 & 1 & 11.3 \\
\hline & $\begin{array}{l}2 \text { Days } \\
\text { After 2nd. Reinj. }\end{array}$ & 66 & 28 & 6 & 29 & 66 & 4 & 0 & 12.2 \\
\hline & $\begin{array}{l}\text { Before } \\
\text { 3rd. Reinject. }\end{array}$ & 95 & 3 & 2 & 51 & 45 & 3 & 1 & 11.2 \\
\hline & $\begin{array}{c}1 \text { Day } \\
\text { After 3rd. } \mathrm{R} \text {. }\end{array}$ & 66 & 25 & 9 & 1 & 47 & 44 & 8 & 22.2 \\
\hline & $\begin{array}{c}2 \text { Days } \\
\text { After 3rd. R. }\end{array}$ & 48 & 37 & 15 & 2 & 22 & 59 & 17 & 25.1 \\
\hline & $\begin{array}{c}3 \text { Days } \\
\text { After 3rd. R. }\end{array}$ & 82 & 8 & 10 & 1 & 41 & 41 & 17 & 23.1 \\
\hline
\end{tabular}


Fig. 7 Average Mitochondria Counts

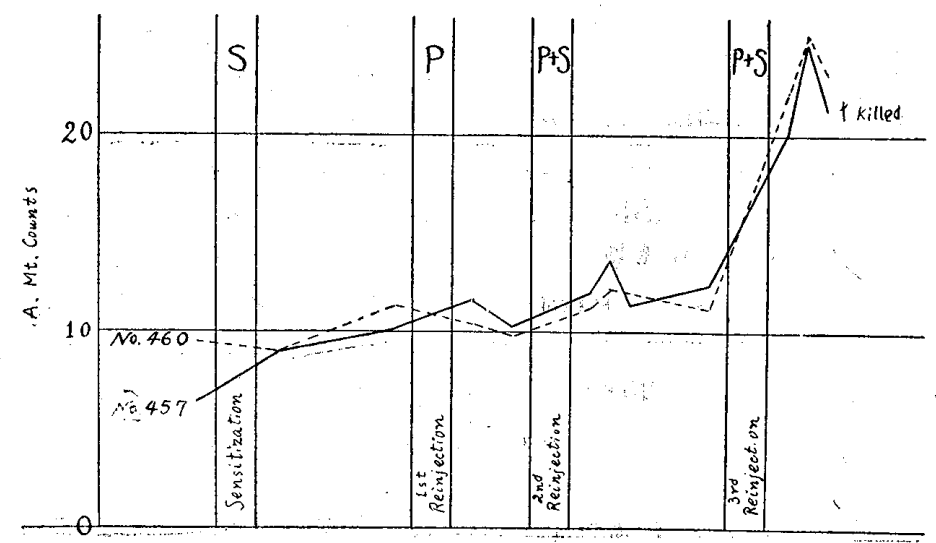

ものは注射前の 5-7 倍に迄增加し，31 個以上 のものは著明嘫し，注射後第 2 日目には淋巴 球の三分の一を占むるに至る. 注射前後の淋巴 球の大きさを比較するに Table 13. に見る如く 著明に大・中型淋巴球が增加し，最高 $78 \%$ に 達する. 以上よりして，超生體染色所見上リン ホン・アレルギーが萑起せられて居ることが判 る. 平均系粒體數は第 2 回再注射後上りも高 く, 最高 28.0 に達する. 又淋巴芽球及びその變 性像も多數出現し，第 1 回票注射時に注射した 淋巴腺「木」加畉蛋白による抗體と結合せるも のと考学らる. No. 461一殆んど No. 458 と同 樣なる變化がみられる.稍々其の變化が No. 458 いが，牛血清感作，淋巴腺「木」再注射，それに引續い て行つた淋巴腺「木」加牛血淸の注射では，その超生體 染色上の戀化に於ては，第 I群に於て述べた牛血清感

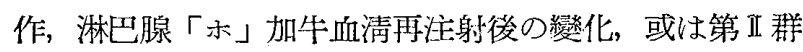
及び第皿群汇於て述べた，淋巴腺「木」加牛血清注射後 3 週の間隔を和いて同樣に淋巴腺「木」加牛血清で注射 した後の變化比して幾分弱い上うに考学られる。.これ は固定染色標本の血液像上り得た第 3 報の結果已も幾分 異なる. 然し中型淋巴球友び大型淋巴球の出現率を參着 してみると，大型淋巴球特に中型淋巴球の壖加は大略第 $\mathrm{I}$ 群の陽性像伦於けると大差がない: 叉Wintrobe ${ }^{10)}$ の 標準によつて，系粒體數以外の種々なる觀點より觀察す るに；極めて幼若なるもの度び其の變性像としか考元ら れないるのが數多く出現する，變性に陷らてとする幼若 淋巴球万至は淋巴芽球の系粒體は明かに見分けることは 容易ならず，染色し難いか又は一旦染色したるのが早く 見䧼〉なつてゆくのか，香子角系粒體數は餘り多くない 場合沙溇々ある。年の鹪に平均系粒體數が餘り上昇しな からたのではあるまいかとる考党られる。しかし，少く とも他の典型的な陽性像とは多少其の趣を異にしている ようである. (Tab. 12, Fig. 7)

第皿群：No. 458一感作前啳に於て著變はない。ただ 牛血清感作後大型淋巴球が稍々增加している。淋巴腺 「示」加畉蛋白の再注射によつて子殆儿ど變化はみられ ない. 然るにそれに引續いて行つた淋巴腺「木」加牛血 清の再及注射によつて, 糸粒體數 0 -10 個のものが注射 前の 3 分の 1 亿減少し，11-20 個のものが約 3 倍に增加 し，21-30 個の子のが明かに增加している. 31 個以上 のものは變りがない，平均紋粒體數は輕度に筧加してい る, 又小型淋巴球が注射前より牛减して中型淋巴球が約 4 倍增加している。，更に淋巴腺「木」加牛血清の再々注 射(第 2 回再注射) 後 3 週間を經て, 第 3 回再注射として 淋巴腺「木」加甽蛋白を連日 3 日間注射するに, 注射前 糸粒體數 0-10 個のものが $26 ， 11-20$ 個のものが 65 , 21-30 個のものが 8,31 俔以上のものが 1 個湓ぎない が、注射後糸粒體數 0-10 個のものが殆んぞ消失し(1 4 個)，11-20 塯のものは稍々減少するが，21—30 儖の
上り强いものの如くである. 斯くの如くして第四群と略 々同樣の變化を來している. 即ヶ, 牛血清感作後, 再注 射に淋巴腺「木」のみでも，淋巴腺「木」加卵蛋白を用 いても變化なく、それに引續いて淋巴腺「示」加牛血清 を注射すればアレルギー性變化を䓯起するるのと考光ら れるが，超生體染色所見より考察すれば幾分抑制されて いるものの如き觀がある.

一般に系粒體(ミトコンドリア)は細胞質中に散在さる こともあるが，核に近く密集して集霜的に存在すること 子多い，細胞質の周邊部即ち細胞膜に極く近く現われる ことは極めて少ない，その粒は据球比比して大きく且つ

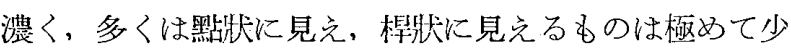
ない，桿狀と見兄るものも上下に少しづつ顯微鏡の筒を 動かして入念灌察せば多くは點㓠の系粒體の逨つてい るもののようである。系粒體の數は淋巴球を立體的に觀 察する場合と平面的炕觀察するのとでは非常な差異を生 ずるので，必ず入念立體的灌察しなければ正確なる 數值を得がたく，平面的觀察では相當誤つた結果となり 易いと考觉られる。

2. 組 織 像

Delafield 21 亿依れば淋巴組織 (Lymphatic tissue) と 稱せらるものは，所謂淋巴腺 (Lymphglands)のみなら ず，胃・晹・墛桃腺・脾・肺・肝々の他の場所をる包括 する, 而して Arnold 22) が示した如く淋巴瀘胞 (Lymphfollicles) 々呼ばれるものは身體の種々なる部位に種々な る量飞廣く撒布されている，肺・肋膜下・胸腺・睡液 腺・肝・腎等。淋巴腺は決して腺ではないという見地よ り，言語の通常の意味に於て，淋巴結節 (Lymphnodes) 々呼び，身體の種々なる場所飞撒布されている淋巴䋊織 の小塊を「淋巴瀘胞」の代りに, 淋巴小結節 (Lymphnodules）と呼ぶ方がいいようである. 斯くして著者は淋

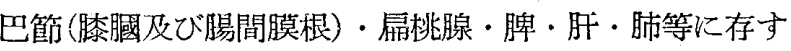

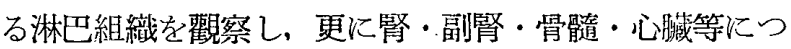
いても檢索した，但し，著者は主として淋巴組織を中心 に述べることにする。

A. 第 I 群 $(\mathrm{S} \cdot \cdots . . \mathrm{P}+\mathrm{S})$ の No. 463, No. 464 屿第 3 回 再注射後 8 日目に致死，剖檢，組織標本を作製した。 
Table 13. (4th Group)

\begin{tabular}{|c|c|c|c|c|c|c|c|c|c|}
\hline \multirow[b]{2}{*}{ No. } & & \multicolumn{3}{|c|}{ Size } & \multicolumn{4}{|c|}{ Mitochondria Counts } & \multirow{2}{*}{$\begin{array}{c}\text { Average } \\
\text { Mt } \\
\text { Counts }\end{array}$} \\
\hline & & Small & $\begin{array}{l}\text { Inter- } \\
\text { mediate }\end{array}$ & Large & $0-10$ & $11-20$ & $21-30$ & 31 more & \\
\hline \multirow{12}{*}{458} & $\begin{array}{c}\text { Before } \\
\text { Sensitization }\end{array}$ & 82 & 16 & 2 & 68 & 32 & 0 & 0 & 9.0 \\
\hline & $\begin{array}{c}\text { After } \\
\text { Sensitization }\end{array}$ & 75 & 17 & 8 & 67 & 32 & 1 & 0 & 9.8 \\
\hline & $\begin{array}{c}\text { Before } \\
\text { 1st. Reinject. }\end{array}$ & 94 & 4 & 2 & 69 & 30 . & 1 & 0 & 9.0 \\
\hline & $\begin{array}{c}1 \text { Day } \\
\text { After 1st. Reinj. }\end{array}$ & 92 & 7 & 1 & 54 & 45 & 0 & 1 & 10.5 \\
\hline & $\begin{array}{l}\text { 2Days after 1st. R. } \\
\text { (Before 2nd. R.) }\end{array}$ & 91 & 9 & 0 & 75 & 25 & 0 & 0 & 9.2 \\
\hline & $\begin{array}{l}1 \text { Day } \\
\text { after 2nd. Reinj. }\end{array}$ & 77 & 23 & 0 & 43 & 49 & 8 & 0 & 12.6 \\
\hline & $\begin{array}{l}2 \text { Days } \\
\text { After 2nd. Reinj. }\end{array}$ & 58 & 41 & 1 & 25 & 70 & 5 & 0 & 13.1 \\
\hline & $\begin{array}{l}3 \text { Days } \\
\text { After 2nd. Reinj. }\end{array}$ & 59 & 40 & 1 & 26 & 65 & 8 & 1 & 12.8 \\
\hline & $\begin{array}{c}\text { Before } \\
\text { III Reinjection }\end{array}$ & 89 & 9 & 2 & 26 & 65 & 8 & 1 & 13.2 \\
\hline & $\begin{array}{c}1 \text { Day } \\
\text { After 3rd. Reinj. }\end{array}$ & 48 & 41 & 11 & 4 & 40 & 44 & 12 & 22.1 \\
\hline & $\begin{array}{l}2 \text { Days } \\
\text { After 3rd. Reinj. }\end{array}$ & 22 & 58 & 20 & 0 & 19 & 48 & 33 & 28,0 \\
\hline & $\begin{array}{c}3 \text { Days } \\
\text { After 3rd Reinj. }\end{array}$ & 71 & 23 & 6 & 1 & 37 & 57 & 5 & 22.5 \\
\hline \multirow{9}{*}{461} & $\begin{array}{c}\text { Before } \\
\text { Sensitization } \\
\end{array}$ & 90 & 10 & 0 & 76 & 24 & 0 & 0 & 8.7 \\
\hline & $\begin{array}{c}\text { After } \\
\text { Sensitization } \\
\end{array}$ & 73 & 24 & 3 & 66 & 31 & 2 & 1 & 9.8 \\
\hline & $\begin{array}{c}\text { Before } \\
\text { 1st. Reinject. }\end{array}$ & 86 & 12 & 2 & 40. & 55 & 5 & 0 & 11.8 \\
\hline & $\begin{array}{c}1 \text { Day } \\
\text { After 1st. Reinj. }\end{array}$ & 92 & 6 & 2 & 64 & 35 & 0 & 1 & 10.3 \\
\hline & $\begin{array}{l}\text { 2Days After 1st. R. } \\
\text { (Before 2nd. R.) }\end{array}$ & 86 & 9 & 5 & 68 & 28 & 4 & 0 & 10.2 \\
\hline & $\begin{array}{r}1 \text { Day } \\
\text { After } 2 \text { 2nd. R. }\end{array}$ & 48 & 50 & 2 & 20 & 67 & 13 & 0 & 14.7 \\
\hline & $\begin{array}{c}2 \text { Days } \\
\text { After 2nd. R. }\end{array}$ & 49 & 55 & 6 & 15 & 64 & 15 & 6 & 16.5 \\
\hline & $\begin{array}{c}3 \text { Days } \\
\text { After } 2 \text { nd. } R .\end{array}$ & 44 & 52 & 4 & 20 & 64 & 15 & 1 & 15.0 \\
\hline & $\begin{array}{c}17 \text { Days } \\
\text { After 2nd. R. }\end{array}$ & 91 & 6 & 3 & 39 & 53 & 6 & 2 & 12.2 \\
\hline
\end{tabular}

Fig. 8 Average Mitochondria Counts,

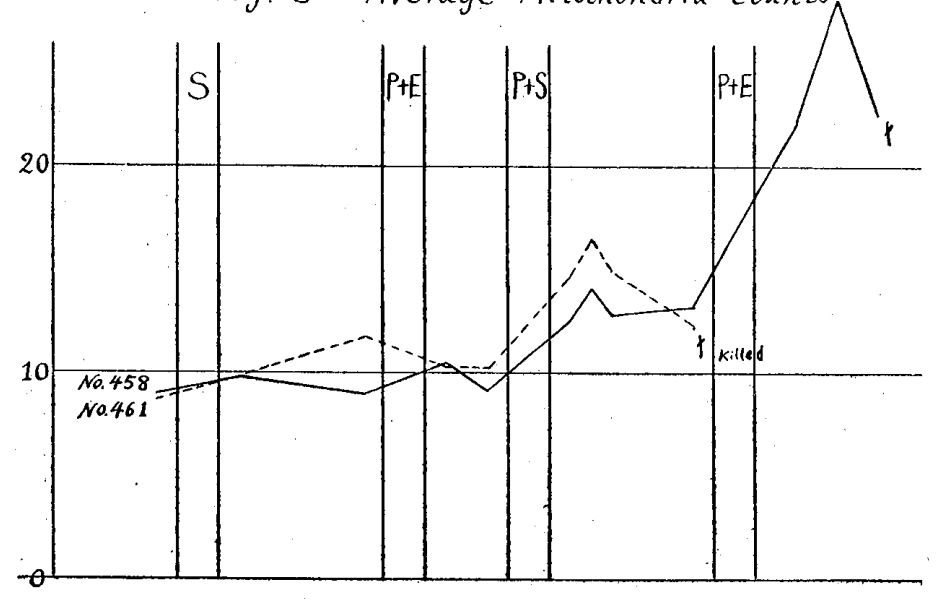

B. 第市群 $(\mathrm{S} \cdots \cdots \mathrm{S} \quad \mathrm{P}+\mathrm{S} \cdots \cdot \mathrm{P}+\mathrm{S})$ の No. 459 ;

第卭群 $(\mathrm{S} \cdots \cdots \mathrm{P} \quad \mathrm{P}+\mathrm{S} \cdots \mathrm{P}+\mathrm{S})$ の No. 457, No. 460 ;

第且狰 $(\mathrm{S} \cdots \cdot \mathrm{P}+\mathrm{E} \quad \mathrm{P}+\mathrm{S} \cdots \cdots \mathrm{P}+\mathrm{E})$ の

No. 458 ;

は第 3 回呫注射後 4 日目に致死, 剖檢, 組織標 本を作製した。

C. 第正群の No. 462 は第 2 回阵注射後 6 日 日に骨髓穿刺の際骨折を來し，值ちに致死せし め剖檢，組織橴本を作製した。符四群の No. 461 は第 3 回洅注射直前に致死せしめ，剖檢， 組織標本を作製した。

A. の No. 459 ; No. 457 , No. 460 ; No. 458 にあつては、リンホン・アレルギーを虑起せる 
Plite 4

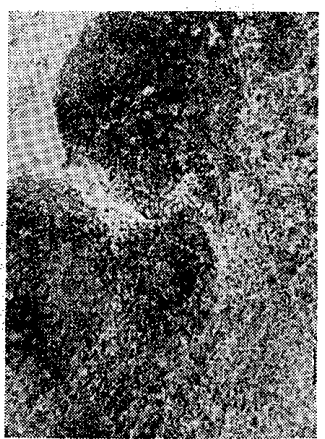

No. 457; Lymphnode, $\times 140$
Plate 5

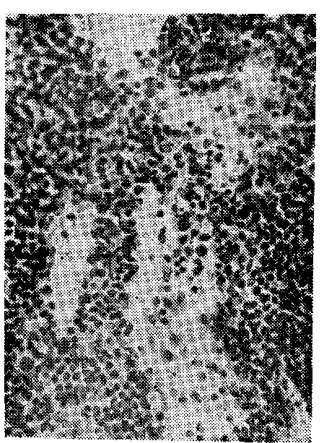

No. 457, Lmyphnode, $\times 600$

直後に組織標本を作製せるものにして，肉眼的に淋巴節 の肥大又は出血を呈するものも女り，その組織像を鏡檢 するに，各例とも，芽中心は殆えど消失し，淋巴組織は 淋巴性基質が增殖し，中－小の淋巴球が充滿し，淋巴洞 が擴大し (PLATE 4), 內被細胞は剥脫され肥大し，大・ 中淋巴球が充滿し、動員されている狀態にある. 淋巴性 基質の部分に於ける網狀織細胞は增殖・肥大せるを見 る. 又一部分に於てはそれ等の淋巴球が變性像を呈して いる. (Plate 5, Plate 6). へモジデリンの沈着が多く みとめられる。

B. No. 462 及び No. 461 飞あつては、リンホン・ア レルギーを殆んど起していない狀態に於て致死剖檢標本 作製せるものにして，上述の 4 例の組織像とは著明に異 なり，芽中心は極めて明瞭にして、淋巴洞はひきしま り，淋巴性基質の增殖，淋巴球の變狌潒等はみとめられ ない。この像は古賀さ)の璝驗に於けるが如く、蛋白體の 凌榜物質としての作用に基く變化に似たるもののみであ s.

C. 第I 群の No. 463, No. 464kあつてはリンホン・ アレルギーを萑起したる後 8 日後で變化の減退せる時期 に致死・剖檢・組織標本作製せるものにして, 上述の如 き，淋巴組䋨洔異的な變化は極めて少くなつている. (Plate 7)

嵋桃腺 (Plate 8), 脾 (Plate 9) に於ても, リン木 ン・アレルギーを萑起せしめて後4 日目に致死・剖檢・ 組織標本を作製せるものにあつては，上述の淋巴結篩に

Plate 8

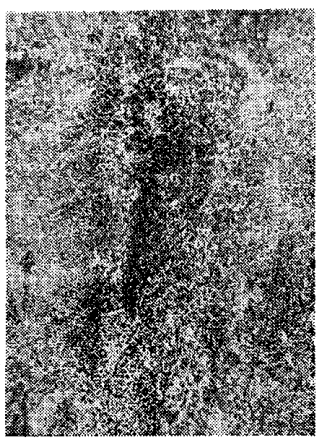

No. 453 Tonsil, $\times 12 \mathrm{~J}$
Plate 9

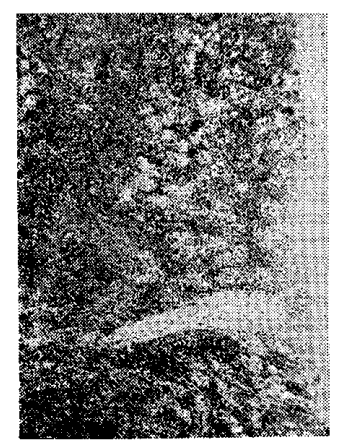

No. 460 Spleen, $\times 44$
Plate 6

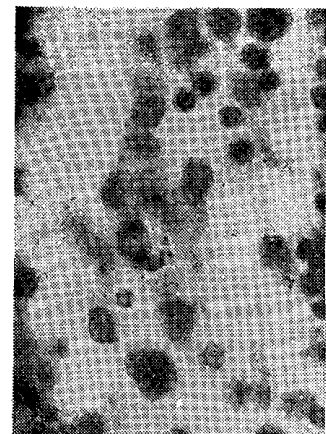

No. 457, Lymphnode, $\times 1,8 \overline{0} 0$
Plate 7

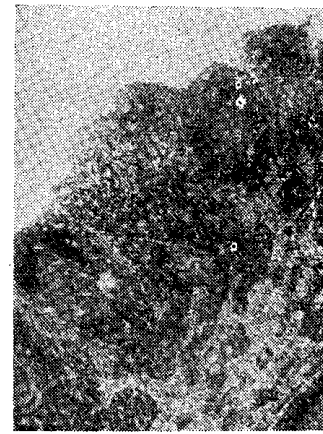

No. 4j4, Lymphnode, $\times 120$

於ける變化と略々同樣なる變化をみとめることが出來 る.

心臟は心筋萎縮變性を輕度にみとめ，間質及び血管周 園に圓形細胞浸潤を僅かに見得るが，その程度は輕微に して,アショッフ結節の如き像はみとめられない(PLATE 10). No. 457 に於て圓形細胞浸潤は線狀又は熙狀, No. 460 は略々 No. 457 と同樣，No. 459 は束狀でやや强 く, No. 458 は線狀文は點狀，No. 461 は殆んぞなく, No. 462 はやや强く. No. 463, No. 464 は殆んどない. No. 463 に於て心被膜下に束少しある. 腎㤝血定認め る外著變はない，全然變化らしきものを多々めない例も ある.肝沈於ては（PLATE 11）肚管・肝血管周園に輕度 の圓形細胞浸潤をみとむるものもあるが，概小著明な有 意義な變化はみとめがたい. Kupfer の星芒細胞 (Sternzellen) にも著變なく，肝組胞障碍もみとめがたい。副 製には特異的變化はみとめられない，骨髓は脂脏組織が 稍々多く，巨核球を諸所に見得る. 以上の組織像上り， リンホン・アレルギーを惹起したる場合には淋巴組織が 選擇的に侵襲され，それに應じて增殖性變化を誘起し， 淋巴組織にて一部は抑留處理されるが，一部は未梲血液 に流出し，淋巴球增多を件い，幼若淋巴球の多數出現並 に淋巴芽球及び其の變性像が出現するものと考兄られ る. 然るにリンホン・アレルギーを惹起していない場合 には組織像は蛋白體の凌嵄物質としての作肞に基く戀化 にして、淋巴球系に選擇的にアレルギ一性變化を誘起せ ず，從つて未梢血液に於ても著變を爻ないものと考光ら

Pla'te 10

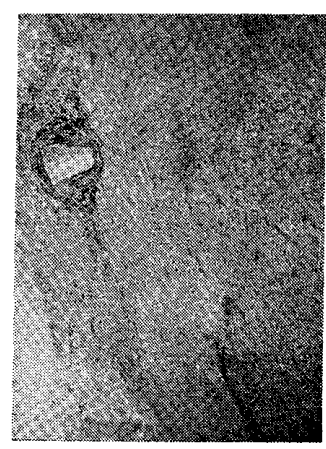

No. 457 Heart, $\times 60$
Plate 11

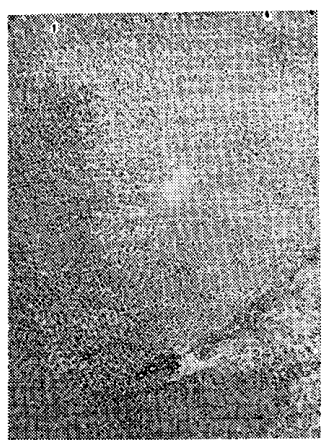

No. 458 Liver, $\times 90$ 
れる。

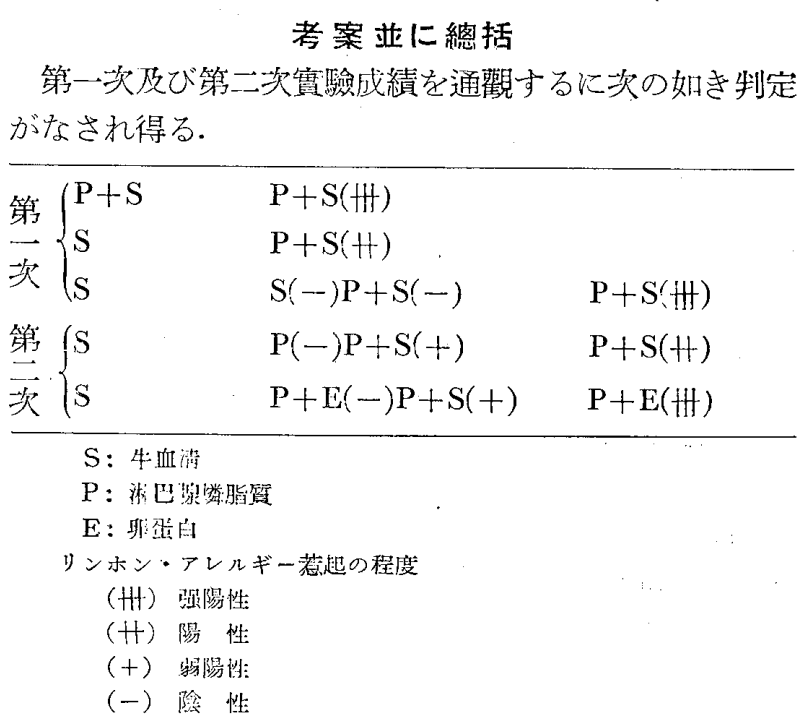

以上の賽硆成績を以てりンホン・アレルギーを分析す るに，第 1 報緒論に於て述べた如く $\mathrm{P}+\mathrm{S}$ 亿て感作せば

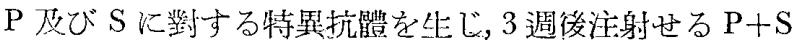

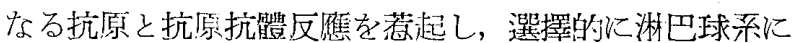
のみアレルギー性戀化を强度汇莠起せしめる。感作を $\mathrm{P}+\mathrm{S}$ の代りに $\mathrm{S}$ を以てするも，再注射火 $\mathrm{P}+\mathrm{S}$ を注: 射せば，リンホン。アレルギーを起すことを考兄れば，

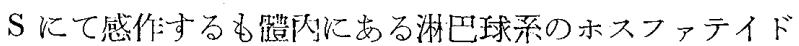
が牛血清と結合して P $+\mathrm{S}$ で感作したような結果になる ものと考光られる。然し，淋巴球系に宓つては，Sで感 作した場合は P +S で感作した場合に比し，平均糸粒體 數の上昇，淋巴芽球灭び其の絵性像の出現等に於ては餘 り境晎はないが，幼若大型淋巴球及び中型淋巴球出現は 前喤が最高 40 - $55 \%$ である對し，後都は最高 $75 \%$ で

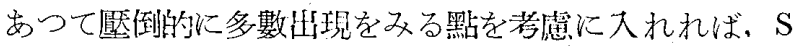
感作の場合の方がその陽性度が稍及低いものと考光ざる

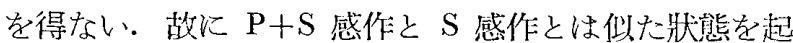
すけれぞも必ずしも全く同楾な結果をもたらさないるの と考觉られる。

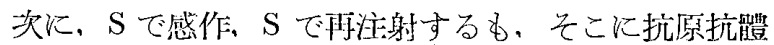
反㺘を惹起することは明かであるが，淋巴球系汇のみ限 局したアレルギー性變化はみられない，即ちリンホン。 アレルギーは起らない。然も引續いて行つた $\mathrm{P}+\mathrm{S}$ の再 及注射によるるリンホン・アレルギーは花起されない。 即ち再注射火大れた抗原 $\mathrm{S} て ゙ \mathrm{~S}$ 感作に上る抗體と結合 して，起るべきリンホン・アレルギーが殆んど完全に抑 制され脱感作されている. 更に 3 週間後 $\mathrm{P}+\mathrm{S}$ で再々及 注射すると强陽性となるのは，再从注射に大れた抗原 $\mathrm{P}+\mathrm{S}$ で舴び感作されたものと考光られる. 然るた， S で感作，Pで車注射を行うに，變化はなく，引續いて行 つた P+S の再注射で国定標本で怯陽性像明かなるも， 平均系䊀體數の上昇は左程著明でなく, 幾分玶注射の $\mathrm{P}$ で抑制されているのではないかと考光られる。 それは $\mathrm{S}$ で感作するる，上述せる如く，體內にある桷巴球系の木
スファテイド (small p) と一部分結合して, $\mathrm{P}+\mathrm{S}$ で感

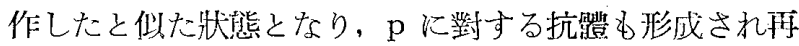
注射に大れた large $\mathrm{P}$ と一部分結合するため，引續いて 陆及注射に大れた抗原 $\mathrm{P}+\mathrm{S}$ と大部分結合してそこに程 度は稍々低いがリンホン・アレルギーを薏起するものと

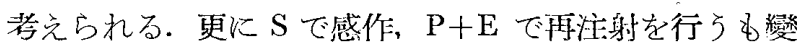
化は㱠んぞ認められない，それは抗原 S の注射によつ て作られた $\mathrm{S}^{\prime}$ と再注射炕入れた $\mathrm{P}+\mathrm{E} の \mathrm{E}$ (贸蛋白) と は抗原抗赠反應を扢さないことを物語る（蛋白の種屬特 異性)，しかし直ぐ上に述べた如く，S で感作寸れば， 體內の small $\mathrm{p}$ と結合して $\mathrm{p}+\mathrm{S}$ で感作したと同じ結 果となり， $\mathrm{p}^{\prime}+\mathrm{S}^{\prime}$ なる抗體を生じ，その $\mathrm{p}^{\prime}$ が再注射に 入れた抗原 $\mathrm{P}+\mathrm{E}$ の large $\mathrm{P}$ と一部分結合して小規模 の抗原抗體反應を抗こすが決して完全には扣制され脫感 作されない，故に引續き $\mathrm{P}+\mathrm{S}$ の再及注射によつて程度 は稍々低いがリンホン・アレルギーを惹起する，第皿群

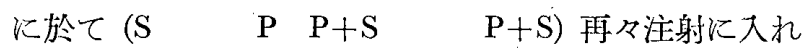
た $\mathrm{P}+\mathrm{S}$ の 3 週間後更に $\mathrm{P}+\mathrm{S}$ を注射すればリンホン・ アレルギーを惹起するがその陽性度は第Ｉ群（S-P+ S) のそれ之略及同樣であつて，第群 $(\mathrm{S}-\mathrm{S}-\mathrm{P}+\mathrm{S}$ - $\mathrm{P}+\mathrm{S})$ の最後の陽性度よりは低い之考光られる。 そ の理由は恐らくは第近群の場合は再々注射に入れた $\mathrm{P}+$

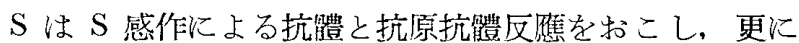
時日の經過と共にその結合が解離して P $+\mathrm{S}$ は抗原とし

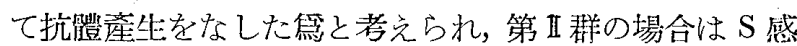
作による抗腼は再注射に入れた $\mathrm{S}$ と㱠えど完全に結合

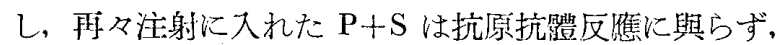

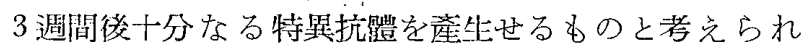
る. 第代群の場合は更に抗原抗體反應を惹起せしめた玨 注射芤 $\mathrm{S}$ もとの後解離して抗原として抗體產生 をなすであろう、以上を總括せば，淋巴腺ホスファテイ ドは種屬特異性を有しないが，强度の，漱巴組織に對す

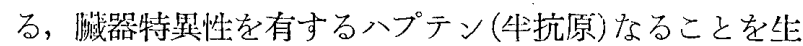
骴內に於て證明せられたるのと考㝋られる。

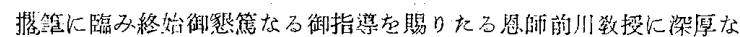

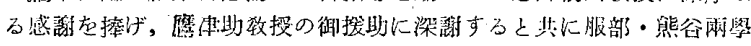

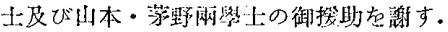

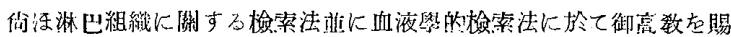

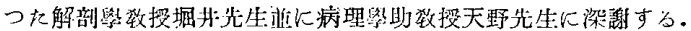

本諭文の要旨时炤和 25 年 4 月第 47 回内科學會，第 12 回日本血 液學會春影總會に於て退告した。

\section{References}

1) Takagi, S., Jikken Keitaigaku, Report 5: 59, Showa 24.

2) Guilliermond, A., Rév. gén. Bot., 30: 161-177, 1918; Les constituants morphologique du cytoplasme: Le chondriome. Actualités scientifiques et industrielles, 170, Paris 1934.

3) Giroud, A., Recherchez sur la nature chimique du chondriome. Protoplasma, 7 : 72, 1929.

4) Hurst, C. T. and Strong, J. G., Arch. f. Protist., 77: 395, 1932. 
5) Kater, J. McA., Anat. Rec. 49: 186, 1931.

6) Clark, J. A. and Hair, G. E., Z. Zellf. mikr. Anat. 15 : 123, 1932.

7) Hall, E. M. and Mac Kay, E. M., Am. J. Path. 9: 205-220, 1933.

8) Pollister, A. W., Am. J. Anat. 50: 179, 1932.

9) Frey. Wyssling, A., Submikroskopische Morphologie des Protoplasmas und seiner Derivate Borntraeger, 1938.

10) Wintrobe., Glinical Haematology, 2nd Ed., 1949.

11) Cowdry, E. V., General Cytology, Chicago, 1924.

12) Bensley, R. R. and Gersh, I., Anat. Rec., 57 : $217,1933$.

13) Bensley, R. R. and Hoerr, N. L., Anat. Rec., 60 : 219-237, 1934.
14) Bensley, R: R., Anat. Rec. 69: 341-353, 1937.

15) Goerner, A., J. Biol. Chem. 122: 529-538. 1938.

16) Joyet-Lavergne, Ph., Protoplasma 6: 84, 1929.

17) Robertson, B., Aust. J. Exp. Biol. a. Med. Sci. 3: $97,1926$.

18) Bourne, G., Aust. J. Exp. Biol. a. Med. Sci. 13: 239, 1935.

19) Ries, E., Z. Zellforschg. 22: 523, 1935-

20) Amano, S., Ketsuekigaku no kiso, Vol. 1: 510, (Showa 23).

21) Delafield, a, Prudden., Text Book of Pathology, 16th Ed., 1935.

22) Arnold, J., Virchow-s Arch. 80: 315, 1880.

23) Koga, S., Hokkaido Igaku Zasshi 13: 2001, Showa 10.

From the Third Medical Clinic of Kyoto University (Director: Professor M. Maekawa, M, D.)

\title{
Clinical and Experimental Study on Venous Return VIII Studies of Venous Réturn and Cardiac Systole in a Patient with Tricuspid Regurgitation
}

$\mathrm{By}$

Manapu TaKashima

(Received for Publication, Nov. 22, 1950)

\section{靜胍還流に關する臨床的並に實驗的研究 第 8 報}

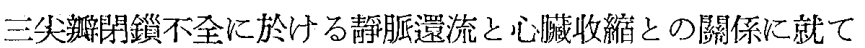

\author{
醫 學士 高嶋學

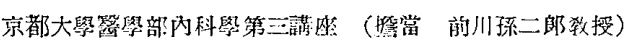

Authois studies on the patterns of venous wave obtained from a patient of relative tricuspid regurgitation established that the auricular suction mechanism

緒

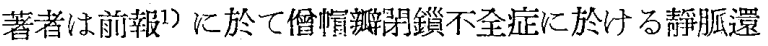

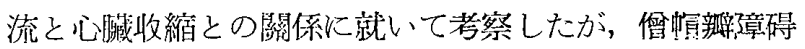

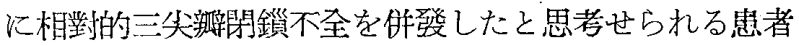

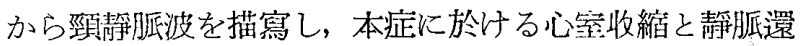
流との關係に就いて若干の知見を得たので報告する。

\section{惯 驗 方 法}

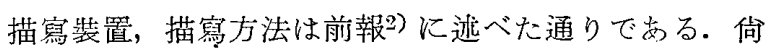
頸動脈波站びに食道心房曲線をも描䳆し頸靜脈波分析上 の參考とした.

被檢者㞸○真○ 38 子男子, 臨床診断; 輕度代償不 全性僧帽瓣障碍 (特汇瓣口狹窄症) 策相對的三尖瓣開鎻不

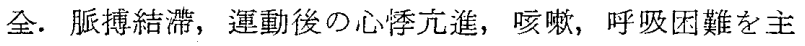
訴とし, 家族歷に結核、腦湓血、癌等有り、既往歷とし was present even in such condition, and that suctionpower depended upon the strength of ventricular systole.

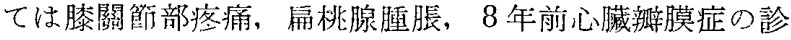

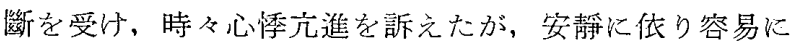
消褪した。現病歷心昨年の慕より心悸六進, 呼吸困難,

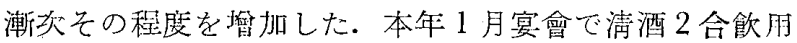
乙歸宅，その夜就寢中心臟部の苦悶感，呼吸困難，血痰 を喀出したと言う。入院時所見としては體骼㮡養共に中 等度，耳殼，口唇「チアノーゼ」，頸靜脈怒張，牛心型

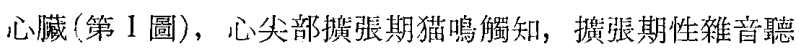
取，三头瓣口罍診部に收縮期性椎音聽取，肺活量 $2600 \mathrm{cc}$, 肝臟腫脹 3 橫指徑, 絕對性不整脈，最高血壓 $117 \mathrm{mmHg}$, 最低血厴 $50 \mathrm{~mm} \mathrm{fg}$, 青爭脈厴 $233 \mathrm{mmH}_{2} \mathrm{O}$, 肢誘導心電 圖には心房細動，心筋障碍等の所見が忠る。

\section{䔬嗝成績泣びに考按}

第 2 圆 a は本患者より描寫した頸動脈波である. 頸 